TRIDARMA: Pengabdian Kepada Masyarakat (PkM), 5 (1) (2022) 49-61

Published by: Institute of Computer Science (IOCS)

TRIDARMA: Pengabdian Kepada Masyarakat (PkM)

Journal homepage: www.iocscience.org/ejournal/index.php/abdimas

\title{
Sosialisasi Penerapan Perilaku 3M (Menggunakan Masker, Menjaga Jarak dan Mencuci Tangan Pakai Sabun) di Era New Normal di Lingkungan Satuan Pendidikan SD Negeri 037 Karya Indah
}

\author{
Nelly Karlinah, Berliana Irianti, Cecen Suci Hakameri, Rahayu Cahyani, \\ Azzahra Haya Yusriyah
}

STIKes Hang Tuah Pekanbaru, Jl. Mustafa Sari No.5 Tangkerang Selatan, Pekanbaru

Email: nellykarlinah87@gmail.com

\begin{abstract}
Abstrak
Awal mula Covid-19 ditemukan pada bulan desember 2019 di Wuhan, Cina. Virus ini tergolong virus baru, Word Health Organization (WHO) menetapkan pada tanggal 07 januari 2020 virus ini dinamakan COVID-19. Di I. ndonesia mulanya kasus COVID-19 terdapat 3 pasien berasal dari kota Depok, dan ketiganya dinyatakan sembuh. Kasus Covid-19 provinsi pada tanggal 21 januari tercatat sebanyak 27.738 kasus positif, sebanyak 25.606 sembuh dan 651 meninggal dunia. Sementara di kabupaten Kabupaten Kampar tercatat 2.110 kasus positif dan di Kecamatan Tapung tercatat 25 kasus positif, 23 kasus sembuh dan 2 kasus meninggal dunia. Hingga saat ini bidang pendidikan sangat berdampak karena Covid-19, pada tanggal 2 maret 2020 kasus pertama Covid-19 ditemukan di Indonesia. Pelaksanaan 3M dilingkungan satuan pendidikan antara lain memastikan lingkungan sekolah menerapkan protokol kesehatan baik yang tatap muka (PTM). Sekolah Dasar Negeri 037 Karya Indah merupakan salah satu sekolah dasar di satuan pendidikan. hingga saat ini masih termasuk pada zona kuning, mulai semester genap januari 2021 kepala sekolah membuat kebijakan untuk pembelajaran tatap muka dengan cara masuk secara bergantian untuk itu dirasa perlu untuk guru dan peserta didik untuk diberikan sosialisasi perubahan perilaku di era new normal terkait disiplin menggunakan $3 \mathrm{M}$ (memakai masker, menjaga jarak dan mencuci tangan). Kegiatan pengabdian ini dilaksanakan pada bulan 25 Februari 2021, jam 08:30 WIB - selesai ,metode pelaksanaan kegiatan yang akan dilaksanakan adalah Penyuluhan, Percontohan menggunakan 3M (Menggunakan Masker, Menjaga Jarak dan Mencuci Tangan Pakai Sabun) dan memberikan edukasi dengan menggunakan banner.
\end{abstract}

Kata Kunci: Penerapan Perilaku 3M, Era New Normal

\section{Pendahuluan}

Awal mula Covid-19 ditemukan pada bulan desember 2019 di Wuhan, Cina. Virus ini tergolong virus baru, Word Health Organization (WHO) menetapkan pada tanggal 07 januari 2020 virus ini dinamakan COVID-19. Pada tanggal 10 Februari 2020 ada lebih 43.000 jiwa dinyatakan positif Covid-19 dan meninggal dunia 1.017 jiwa, selain itu lebih 21.000 orang diduga terinfeksi. Pada tanggal 32 januari WHO mengumumkan wabah COVID-19 di Cina sebagai Emergency Health Public of Concern Internasional (Chang Le, 2020).

Di Indonesia mulanya kasus COVID-19 terdapat 3 pasien berasal dari kota Depok, dan ketiganya dinyatakan sembuh. Namun hingga saat ini kasus COVID-19 di Indonesia meningkat setiap harinya, hari ini pada tanggal 18 september 2020 Satuan Tugas Penanganan Covid-19 melaporkan 236.519 kasus konfirmasi positif Covid-19 dengan 56.409 kasus aktif, 170.774 sembuh dan 9.336 meninggal dunia (Kemenkes, 2020).

Kasus Covid-19 provinsi pada tanggal 21 januari tercatat sebanyak 27.738 kasus positif, sebanyak 25.606 sembuh dan 651 meninggal dunia. Sementara di kabupaten Kabupaten Kampar tercatat 2.110 kasus positif dan di Kecamatan Kampar Kiri Hilir tercatat 25 kasus positif, 23 kasus sembuh dan 2 kasus meninggal dunia (Pemerintah Provinsi Riau, 2021). 
Hingga saat ini bidang pendidikan sangat berdampak karena Covid-19, pada tanggal 2 maret 2020 kasus pertama Covid-19 ditemukan di Indonesia siswa masih belajar di satuan pendidikan, tanggal 9 maret 2020 Mendikbud mengeluarkan protocol pencegahan covid dan siswa masih belajar, kemudian tanggal 24 maret 2020 Kemendikbud mengeluarkan kebijakan belajar dari rumah (BDR), pada tanggal 15 juni 2020 Mendikbud, Menag, Mendagri dan Menkes mengumumkan kebijakan pembelajaran tatap muka di satuan pendidikan boleh dilakukan di zona hijau dengan persyaratan dan pada tanggal 7 agustus 2020 penyesuaian kebijakan pembelajaran tatap muka di satuan pendidikan boleh dilakukan di zona hijau dan kuning, siswa di zona oranye dan merah masih belajar dari rumah (Kemendikbud, 2020).

Pelaksanaan $3 \mathrm{M}$ dilingkungan satuan pendidikan antara lain memastikan lingkungan sekolah menerapkan protokol kesehatan baik yang tatap muka (PTM) maupun masih belajar dari rumah (BDR), melakukan deteksi dini dan mitigasi penyebaran Covid-19, memastikan ketersediaan saran dan media KIE 3M, berkoordinasi dengan dinas pendidikan dan stgas penganganan covid-19 setempat untuk pelaksanaan protokol kesehatan di sekolah dan di perjalanan, membuat program apresiasi dan duta $3 \mathrm{M}$ dari pendidik, peserta didik dan keluarga patuh 3M dan mendokumentasikan praktik baik 3M di sekolahnya (Kemendikbud, 2020).

Sekolah Dasar Negeri 037 Karya Indah merupakan salah satu sekolah dasar di satuan pendidikan. hingga saat ini masih termasuk pada zona kuning, mulai semester genap januari 2020 kepala sekolah membuat kebijakan untuk pembelajaran tatap muka dengan cara masuk secara bergantian untuk itu dirasa perlu untuk guru dan peserta didik untuk diberikan sosialisasi perubahan perilaku di era new normal terkait disiplin menggunakan $3 \mathrm{M}$ (memakai masker, menjaga jarak dan mencuci tangan) untuk mencegah dan mengendalikan penyebaran Covid-19. dari hasil survey yang ditemukan masih didapatkan siswa dan lingkungan sekolah yang tidak mengetahui tentang 3M.

\subsection{Tujuan Kegiatan}

Untuk memberikan sosialisasi Penerapan Perilaku 3M (Menggunakan Masker, Menjaga Jarak dan Mencuci Tangan Pakai Sabun) pada Era New Normal di Satuan Pendidikan SD Negeri 037 Karya Indah.

\subsection{Manfaat Kegiatan}

Sebagai informasi untuk upaya promosi dan peningkatan mutu kesehatan, khususnya tentang penerapan perilaku 3M (Menggunakan Masker, Menjaga Jarak dan Mencuci Tangan Pakai Sabun).

\subsection{Luaran Pengabdian Kepada Masyarakat}

Target Luaran dalam kegiatan pengabdian kepada masyarakat ini, yaitu:

Siswa mampu menerapkan perilaku 3M (Menggunakan Masker, Menjaga Jarak dan Mencuci Tangan Pakai Sabun).

a. Siswa dan guru mampu menerapkan perilaku 3M (Menggunakan Masker, Menjaga Jarak dan Mencuci Tangan Pakai Sabun).

b. Publikasi hasil pengabdian di jurnal pengabdian kepada masyarakat

\section{Realisasi Kegiatan}

\subsection{Bentuk Kegiatan \& Jadwal, Serta Tempat Kegiatan}

a. Metode Pelaksanaan Kegiatan

Memberikan sosialisasi Penerapan Perilaku 3M (Menggunakan Masker, Menjaga Jarak dan Mencuci Tangan Pakai Sabun) pada Era New Normal di Satuan Pendidikan SD Negeri 037 Karya Indah, Pembagian masker serta cara memakai masker yang benar, Cara mencuci tangan yang baik dan benar, Memberikan banner tentang 3M (Menggunakan Masker, Menjaga Jarak dan mencuci tangan pakai sabun)

\section{b. Waktu Efektif Pelaksanaan Kegiatan}

Kegiatan pengabdian ini dilaksanakan pada tanggal 25 Februari 2021, jam 08:30 WIB-selesai, metode pelaksanaan kegiatan yang akan dilaksanakan adalah :

1) Penyuluhan

Penyuluhan merupakan cara yang paling tepat dalam memberikan pengetahuan kepada lingkungan sekolah untuk memantapkan pelaksanaan kegiatan dan hasil penyuluhan, dengan menyiapkan banner tentang pentingnya 3M (Menggunakan Masker, Menjaga Jarak 
dan Mencuci Tangan Pakai Sabun) pada Era New Normal di Satuan Pendidikan SD Negeri 037 Karya Indah.

2) Percontohan

Memperagakan/mempercontohkan menggunakan 3M (Menggunakan Masker, Menjaga Jarak dan Mencuci Tangan Pakai Sabun) pada Era New Normal di Satuan Pendidikan SD Negeri 037 Karya Indah.

3) Edukasi

Memberikan banner lengkap dengan stand berdiri sebagai sarana edukasi dengan materi 3M (Menggunakan Masker, Menjaga Jarak dan Mencuci Tangan Pakai Sabun).

c. Tempt Kegiatan

Kegiatan pengabdian ini dilaksanakan pada tanggal 25 Februari 2021, jam 08:30 WIB - selesai.

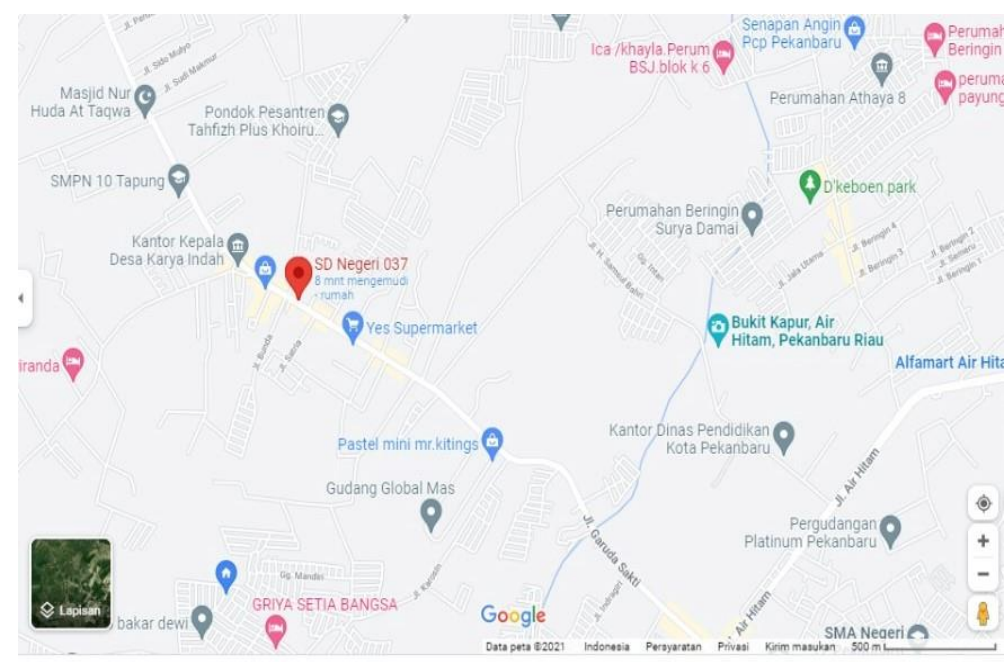

Gambar 1. Maps Lokasi

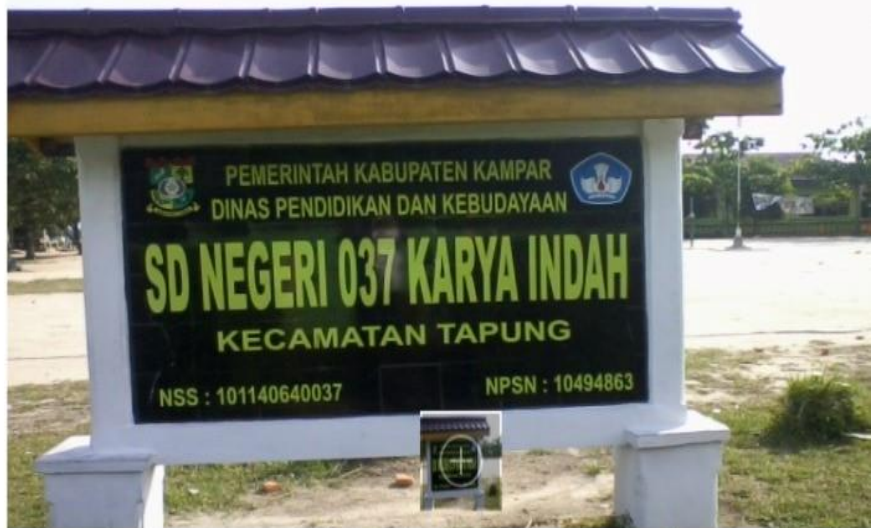

Gambar 2. Lokasi Pengabdian

\subsection{TIM Pelaksana Pengabdian dan TUPOKSI Tugas Pokok serta Peran setiap TIM} Pengabdian

\begin{tabular}{|c|c|c|c|c|}
\hline No & Nama & Jabatan & Pekerjaan & Pembagian Tugas \\
\hline 1 & $\begin{array}{l}\text { Nelly Karlinah, SST, } \\
\text { M. Keb }\end{array}$ & Ketua & Dosen & $\begin{array}{l}\text { 1. Secara umum bertanggung } \\
\text { jawab dalam memimpin dan } \\
\text { mengkoordinasikan seluruh } \\
\text { tahapan kegiatan } \\
\text { pengabdian mulai dari tahap }\end{array}$ \\
\hline
\end{tabular}

Sosialisasi Penerapan Perilaku 3M (Menggunakan Masker, Menjaga Jarak dan Mencuci Tangan Pakai Sabun)... 


\begin{tabular}{|c|c|c|c|c|}
\hline No & Nama & Jabatan & Pekerjaan & Pembagian Tugas \\
\hline & & & & 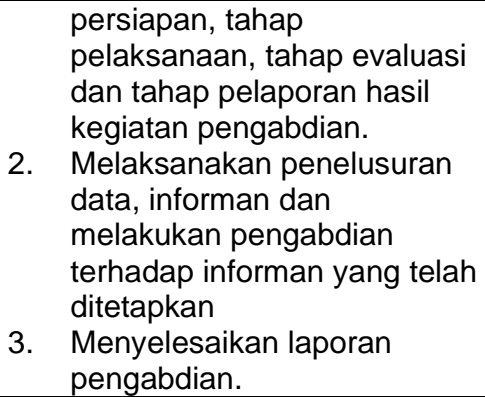 \\
\hline 2 & $\begin{array}{l}\text { Berliana Irianti, S. } \\
\text { SiT, M. Keb }\end{array}$ & Anggota 1 & Dosen & $\begin{array}{l}\text { 1. } \begin{array}{l}\text { Membantu ketua dalam } \\
\text { tahap persiapan, tahap } \\
\text { pelaksanaan, tahap evaluasi } \\
\text { dan pembuatan laporan hasil } \\
\text { pengabdian. }\end{array} \\
\text { 2. Membantu pelaksanaan } \\
\text { penelusuran data, informan } \\
\text { dan melakukan pengabdian } \\
\text { 3. Membantu menyelesaikan } \\
\text { Laporan Hasil pengabdian } \\
\text { dan melakukan publikasi } \\
\text { ilmiah }\end{array}$ \\
\hline 3 & Rahayu Cahyani & Anggota 2 & Mahasiswa & $\begin{array}{ll}\text { 1. } & \text { Membantu proses } \\
\text { pelaksanaan pengabdian } \\
\text { 2. Melakukan dokumentasi } \\
\text { kegiatan }\end{array}$ \\
\hline 4 & $\begin{array}{l}\text { Azzahra Haya } \\
\text { Yusriyah }\end{array}$ & Anggota 3 & Mahasiswa & $\begin{array}{l}\text { 1. Membantu proses } \\
\text { pelaksanaan pengabdian } \\
\text { 2. Melakukan dokumentasi } \\
\text { kegiatan }\end{array}$ \\
\hline
\end{tabular}




\section{3. ingkasan/Garis-garis besar Materi}

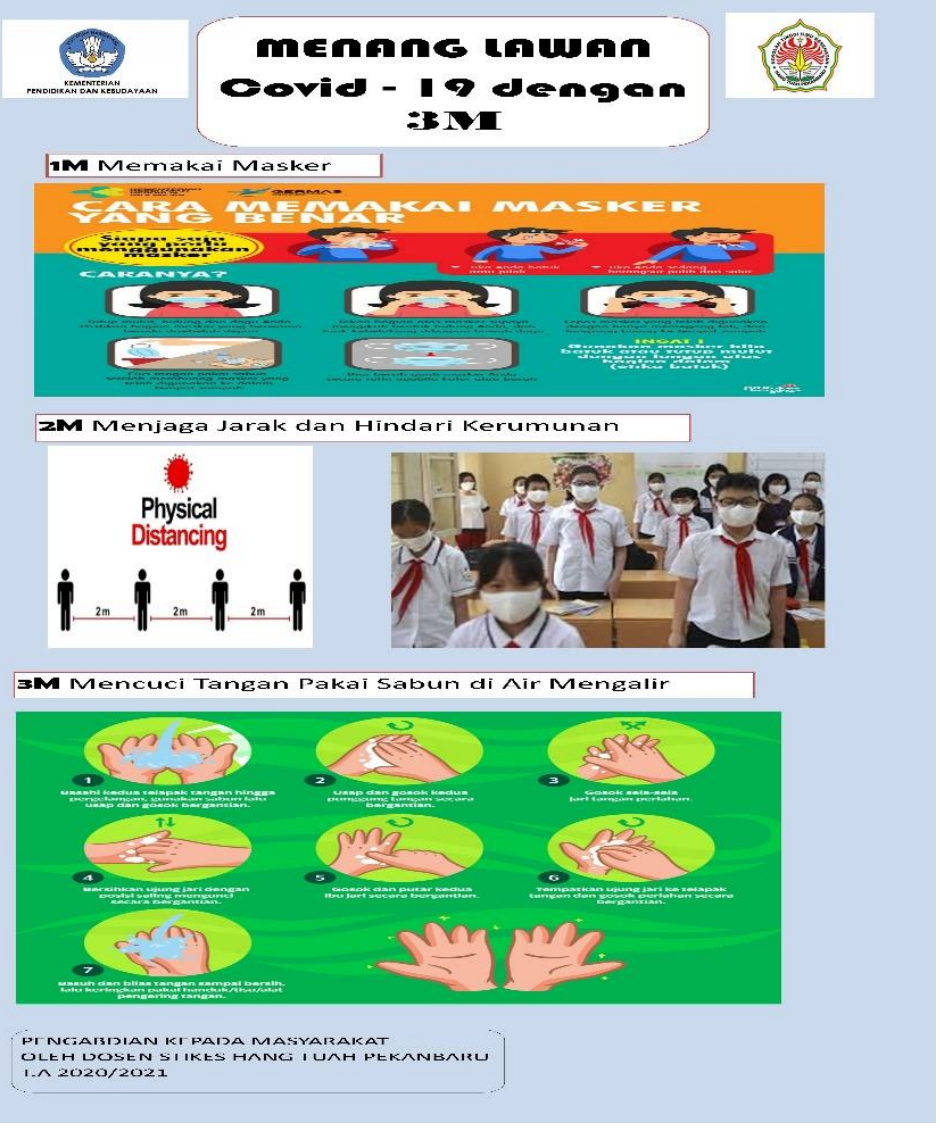

\subsection{Masyarakat Sasaran}

Seluruh Siswa dan guru-guru di satuan pendidikan SD Negeri 037 karya indah, Kec. Tapung Kabupaten Kampar

\section{Tinjauan Hasil Yang Dicapai}

Masih rendahnya pengetahuan murid, guru dan staf penerapan perilaku $3 \mathrm{M}$ (Menggunakan masker, Menjaga Jarak dan Mencuci Tangan Pakai Sabun) di Era New Normal di lingkungan satuan pendidikan di SD Negeri 037 Karya Indah. hal ini disebabkan oleh pengetahuan yang rendah tentang $3 \mathrm{M}$. Hasil dari sosialisasi Meningkatnya pengetahuan dan pemahaman murid, guru dan staf masyarakat tentang penerapan perilaku 3 M (Menggunakan masker, Menjaga Jarak dan Mencuci Tangan Pakai Sabun) di Era New Normal. Hal ini dilihat dari kemampuan murid, guru dan staf. Hal ini dilihat dari kemampuan murid, guru dan staf yang mampu menjawab pertanyaan-pertanyaan yang diberikan pemateri.

Kami mengharapkan agar alternatif pemecahan masalah yang disampaikan dalam kegiatan ini dapat direalisasikan sehingga diharapkan pencapaian penerapan perilaku $3 \mathrm{M}$ (Menggunakan masker, Menjaga Jarak dan Mencuci Tangan Pakai Sabun) di Era New Normal di lingkungan satuan pendidikan di SD Negeri 037 Karya Indah dapat mencapai target yang diharapkan. 


\section{Daftar Pustaka}

Buku Saku PAUD dan Sumber belajar Orang Tuah https://bersamahadapikorona.kemdikbud.go.id/buku-sakupaud/

Informasi kesiapan satuan pendidikan dalam melaksanakan pembelajaran tatap muka disatuan pendidikan http://sekolah.data.kemdikbud.go.id/kesiapanbelajar/home

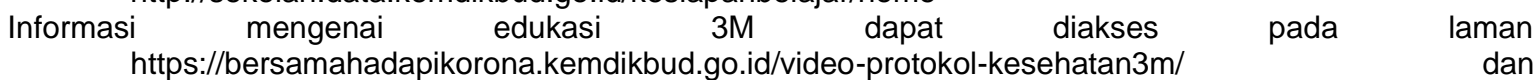
https://covid19.go.id/edukasi/pengantar

Kemenkes RI, (2020). Pedoman Bagi Ibu Hamil dan Bayi Baru Lahir Selama Social Distancing. Direktorat Kesehatan Maternal dan Neonatal, Direktort Kesehatan Keluarga, Kesehatan Masyarakat. Kemenkes ; Jakarta

Kompas, (2020). Jernih Melihat Dunia Update Kasus Covid-19 di Indonesia. https://nasional.kompas.com/read/2020/04/05/15562001/update-total-kasus-covid-19-di-indonesiaada-2273-bertambah-181 di akses 05 April 2020.

Kumpulan Media komunikasi Edukasi Informasi seru belajar kebiasaan baru http://ringkas.kemdikbud.go.id/MediaKIE3M

Lee Chang, Yan Y, Wang L. (2019). Coronavirus Disease 2019 : Coronaviruses and Blood Safety. Transfusion Medicine Reviews Journal. Elsevier. YTMRV-50607 ; Pages 6

Materi pengayaan pendukung belajar dari rumah https://bersamahadapikorona.kemdikbud.go.id/materi-materipengayaan-pendukung-belajar-dari-rumah/

Ministry of Health $(\mathrm{MOH})$ [Indonesia]. Balanced Nutrition for Under Five Healthy Living Children. Jakarta, Indonesia: $\mathrm{MOH} .2002$

Modul Literasi dan numerasi tingkat SD selama Pandemi COVID-19: https://bersamahadapikorona.kemdikbud.go.id/tingkat-sd-modul-belajar-literasi-numerisasi/

Panduan opsi sarana cuci tangan pakai sabun (CTPS) http://ditpsd.kemdikbud.go.id/index.php/panduan-danpedoman/ dan video mengembangkan opsi sarana CTPS secara kreatif dalam mencegah penyebaran virus COVID-19 https://www.youtube.com/watch?v=tK48UXBXaVk

Panduan Pembelajaran Selama Pandemi COVID-19 dan Pedoman Belajar Dari Rumah

World Health Organization. Guiding Principles on Feeding Nonbreastfed Children 6 to 24 Months of Age. Geneva: World Health Organization.2005 


\section{Absensi Pengabdian Kepada Masyarakat}

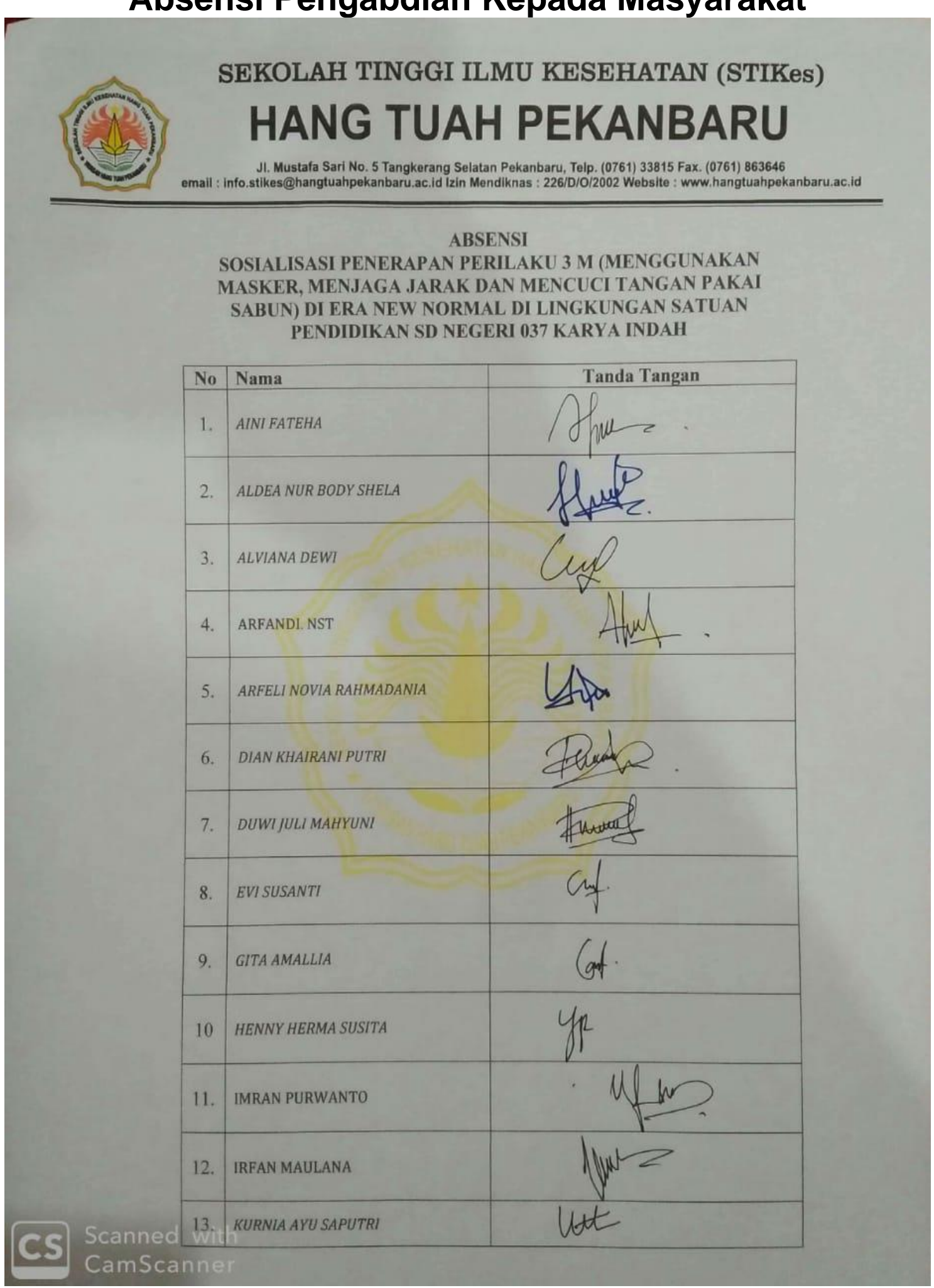

Sosialisasi Penerapan Perilaku 3 M (Menggunakan Masker, Menjaga Jarak dan Mencuci Tangan Pakai Sabun)... 


\section{SEKOLAH TINGGI ILMU KESEHATAN (STIKes) HANG TUAH PEKANBARU}

I. Mustafa Sari No, 5 Tangkerang Selatan Pekanbaru, Telp. (0761) 33815 Fax. (0761) 863646 email : Info.stikes@hangtuahpekanbaru.ac.Id Izin Mendiknas : 226/D/O/2002 Website : www.hangtuahpekanbaru.ac.Id

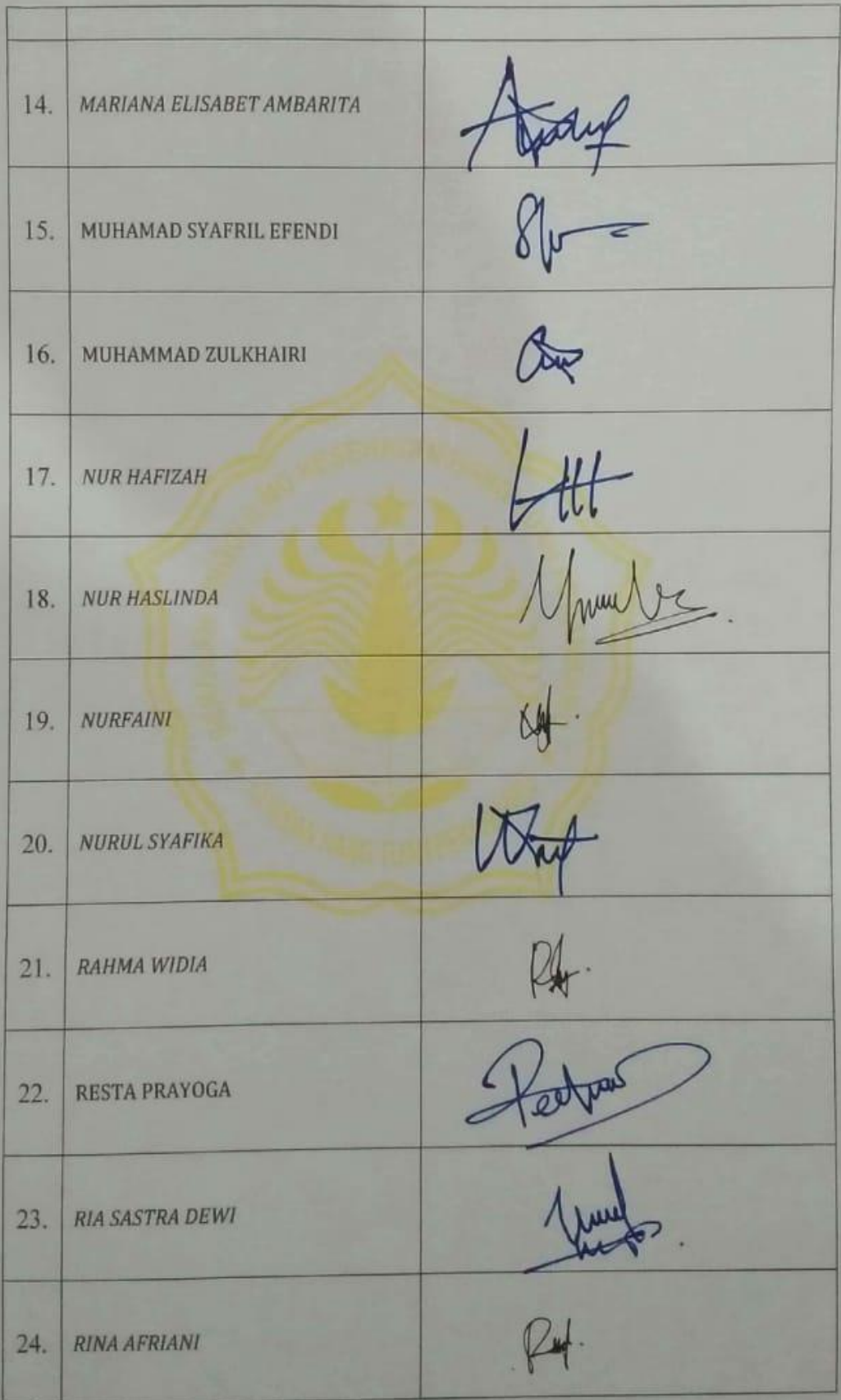




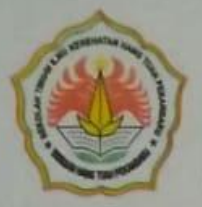

\section{SEKOLAH TINGGI ILMU KESEHATAN (STIKeS)}

\section{HANG TUAH PEKANBARU}

JI. Mustafa Sari No. 5 Tangkerang Selatan Pekanbaru, Telp. (0761) 33815 Fax. (0761) 863646 emall : info.stikes@hangtuahpekanbaru.ac.id Izin Mendiknas : 226/D/0/2002 Website : www.hangtuahpekanbaru.ac.id

25. RISSIKA PRIUTAMI
26. SISKA MAHARANI
27. SYAHRUL RIDWAN
29. YUNDA RAMADANI
30. YUDI AFRIANDI ISNAINI




\title{
Surat Keterangan Melakukan Pengabdian
}

Surat Tugas

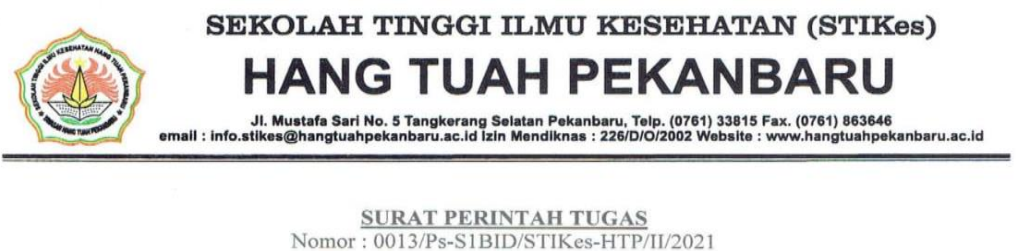

\begin{abstract}
Yang bertandatangan dibawah ini Ketua Program Studi Kebidanan Program Sarjana dan Program Studi Pendidikan Profesi Bidan Program Profesi STIKes Hang Tuah Pekanbaru dengan ini memberikan tugas kepada dosen-dosen program studi untuk melaksanakan Pengabdian Kepada Masyrakat Dana Hibah STIKes Hang Tuah Pekanbaru Periode Semester Ganjil Tahun 2020-2021. Adapun nama dosen terlampir.

Demikian surat tugas ini kami buat, agar dapat dilaksanakan sebagaimana mestinya.
\end{abstract}

Ketua Prodi Kebidanan Program Sarjana dan Program Studi Pendidikan Profesi Bidan

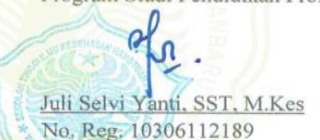




\section{i. Surat balasan melaksanakan pengabdian}

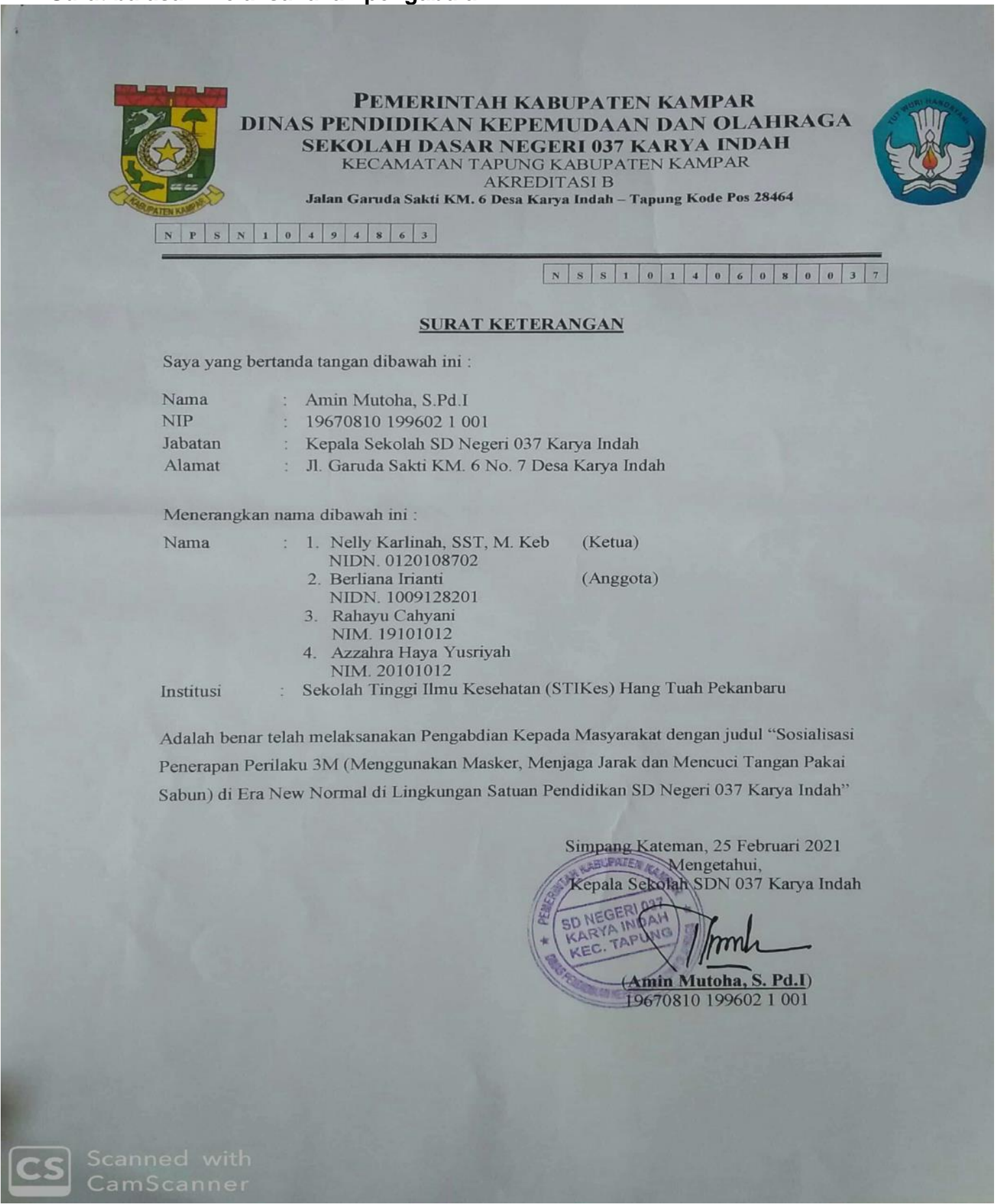

Sosialisasi Penerapan Perilaku 3M (Menggunakan Masker, Menjaga Jarak dan Mencuci Tangan Pakai Sabun)... 


\section{Dokumentasi Kegiatan}
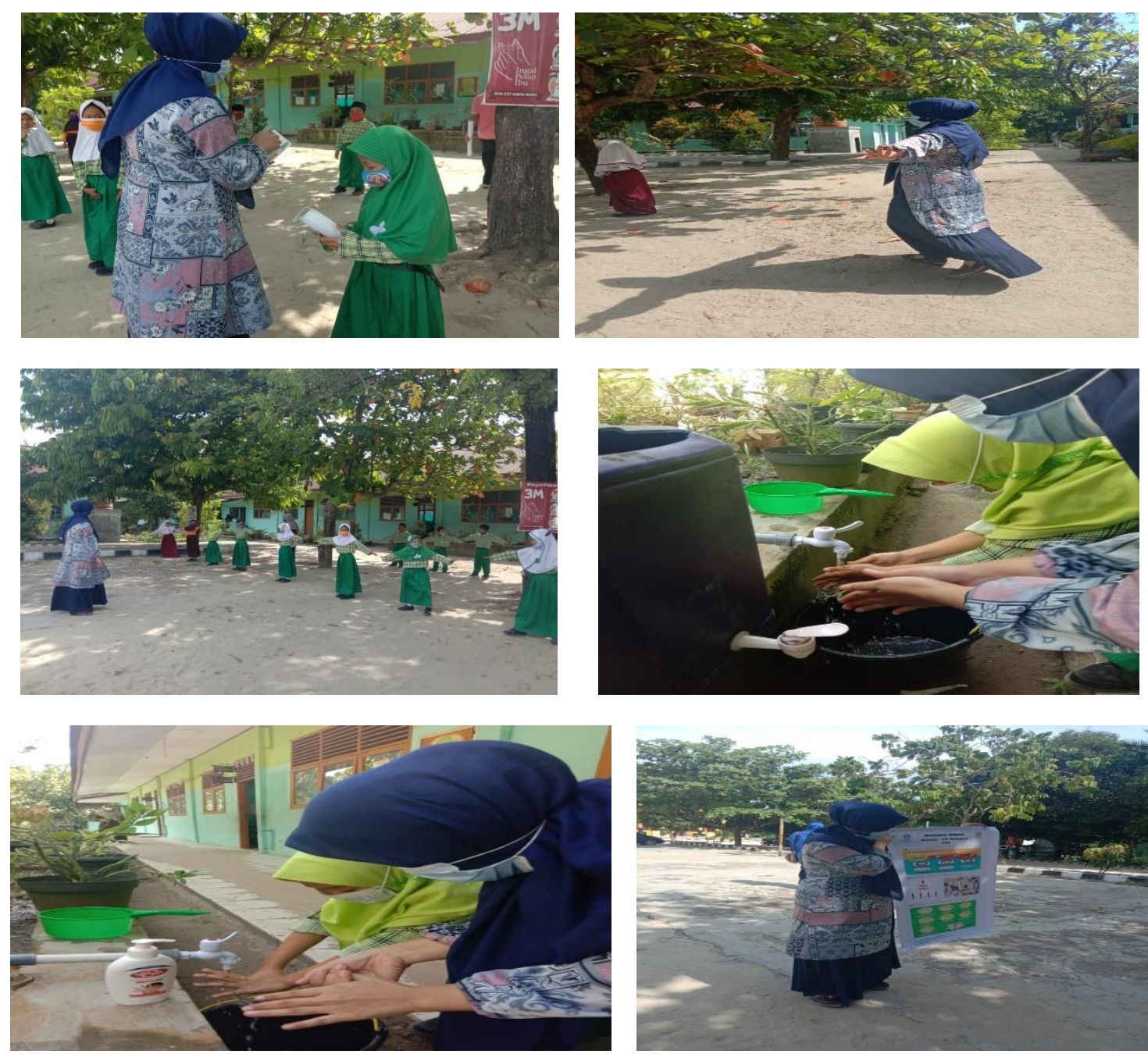